(SHORT COMMUNICATION)

\title{
Kolanut consumption, its benefits and side effects
}

Adejoke Adebusola Adelusi *, Qudus Adebayo Ogunwolu, Chinweike Abednego Ugwu, Modinat Adewunmi Alli, Kehinde Ademola Adesanya, Mutiat Oluwaseyi Agboola-Adedoja and Ayodele Oladipo Akinpelu

\section{Economics and Extension Department, Cocoa Research Institute of Nigeria (CRIN), P.M.B. 5244, Ibadan, Oyo State,} Nigeria.

Publication history: Received on 12 December 2020; revised on 19 December 2020; accepted on 21 December 2020

Article DOI: https://doi.org/10.30574/wjarr.2020.8.3.0483

\begin{abstract}
This article assessed kolanut consumption, its benefits and side effects. Kolanut is the fruit of the kola tree, which is indigenous to West Africa. The two main varieties are Cola acuminata and Cola nitida. It is the most common masticatory in Nigeria, and is quite bitter but gives a sweet taste after chewing. A desk research was done using various published literatures on kolanut. It was unveiled that the consumption of kolanut has many benefits as well as side effects. The side effects are dependent on the quantity intake of caffeine, a significant substance present in kolanut. Caffeine is a stimulant like theobromine and kolanin, which are also present in coffee, tea and chocolate. Kolanuts are chewed fresh and are also in the form of extracts, which is common food flavouring found in energy drinks. Right amount of kolanut depends on factors such as age, physiology and health status, and as such, more effort should be channeled into the area of investigating more appropriate quantity of kolanut that should be consumed in relation to people's status.
\end{abstract}

Keywords: Kolanut; Benefits; Consumption; Side effects; Caffeine

\section{Introduction}

Perennial crops are crops, which are alive year-round and are harvested multiple times before dying [1]. Tree crops are the most common perennial agricultural crop [2]. Almost all of the world's landscapes were covered primarily by perennial plants growing in mixed stands before the introduction of agriculture [3]. Perennial crops are valued for a combination of their total production and the quality of the harvested product [4]. Agriculture can be made far more sustainable by changing many annual agricultural systems to perennial system [1]. Perennial crops include mango, cocoa, cashew, coffee, tea and kolanut.

Kolanut is the seed of the kolanut plant. Other names of kolanut include Arbre à Kola, Bissy Nut, Cola acuminata, Cola nitida, Guru Nut, Gworo, Kola Nut, Kolatier, Noix de Gourou, Noix de Kola, Noix du Kolatier, Noix de Soudan, Soudan Coffee, Sterculia acuminata, Sterculia nitida [5]. In Nigeria, the Igbos call kolanut Oji, the Hausas call it Gworo, while the Yorubas call it Obi [6]. It is the fruit of the kola tree (Cola acuminata and Cola nitida), which are indigenous to West Africa [7].

The kola plant belongs to the cacao family. The classification is in a state of flux. In 2003, following the angiosperm phylogeny, it changed its place from Sterculiacea to Malvaceae [8]. A star-shaped fruit is produced by the trees, which reach heights of 40 to 60 feet. Each fruit contains between two and five kolanuts. This little fruit, which is about the size of a chestnut, is packed with caffeine [7]. There are over 100 species, such as the Cola acuminata and Cola nitida and their leaves can grow as long as $30 \mathrm{~cm}[9]$.

${ }^{*}$ Corresponding author: Adejoke Adebusola Adelusi

aEconomics and Extension Department, Cocoa Research Institute of Nigeria (CRIN), P.M.B. 5244, Ibadan, Oyo State, Nigeria. 
The kola tree can withstand altitudes of up to 1,000 feet (300m) above sea level, provided rich and deep soil is available, though it is typically regarded as a lowland forest species. It requires tropical climate, with an annual average temperature of at least $75^{\circ} \mathrm{F}\left(24^{\circ} \mathrm{C}\right)$ and can tolerate brief dry season, as such can be cultivated in dry regions as long as it is over ground water. Shade is required for the tree to grow well and better results can be enhanced through the addition of good fertilizers [10]. The key chemical constituents of kolanut include: caffeine, theobromine, tannins and phenolics, including d-catechin, 1-epicatechin, and kolanin. Phlobaphens, proteins and starch are also inclusive [11].

The two main varieties are the red and white kola, each of which is produced by the same plant species and sometimes even found within the same pod [12]. The kola tree grows in Brazil, Niger, Liberia, Sierra Leone, Benin, Sri Lanka, and parts of East Africa. It also thrives in humid climates predominantly in Nigeria [9]. Nigeria accounts for about 50.2 percent, which amounts to 139, 216 tons of the total world kolanut production [13].

Kolanut took an inherent role in the formation of West African cultural identities. The "traditional kolanut is considered a sacred nut, which is used to communicate with the gods, it was chosen by the elders as the head or king of all seeds" [14]. In West Africa, the people groups such as Bambara and Malinke of Senegal and Mali used it as a form of currency. It is also being used presently as negotiation over bride prices and as a form of respect [15]. Kolanut is considered among some Nigerian tribes to be the first tree on earth [16]. In Nigerian tradition, kolanut holds great social significance for many ethnic groups and is a very important aspect of tradition [17]. It is an important cultural symbol for many ethnic groups. It is used as medicine and given to guests at funerals, naming ceremonies and at weddings [18]. Kolanuts are prized in cultural practices like community meetings, rites of passage ceremonies for the Igbo people of Nigeria [19]. In a kolanut Igbo ceremony for example, the nut is presented to welcome visitors and used to symbolize peace and goodwill [12]. They are also traditionally chewed to reduce hunger and fatigue, remedy hangovers and aid digestion [19].

Ceremonial breaking of kolanut is important for making people feel welcome in a village or gathering [18]. Due to the European colonization of the region, kolanut later became known across Europe and the Americas and during the slave trade, many of its uses spread to Brazil and the Caribbean. At the start of the $19^{\text {th }}$ century, it was first used as part of the recipe for the first cola drinks [10]. The nuts have tremendous cultural significance, though it is neither the biggest nor the sweetest fruit in Igbo land [20]. The Igbo kolanut (Oji Igbo) 'Cola acuminata', is among the greatest symbol among the Igbo, and belongs to the mysteries of Igbo history, culture and tradition. It serves as a link between human beings and the divine and is used to settle disputes and make peace. It manifests goodwill and symbolizes the well-acclaimed Igbo hospitality [21]. Kolanut symbolizes solemnity, reverence, communion, hospitality and tradition [14, 20].

In determining our Ideologies and characteristic way especially, tradition and religion play major roles in Africa and especially in relation to religion kolanut helps to shape Nigerians' philosophical ideology [20]. Kolanuts can be dried and boiled to make tea. In some parts of Africa, kolanuts have been chewed traditionally as a stimulant but due to the fact that raw kolanuts can stain the teeth and are possibly carcinogenic, this is falling out of practice [10]. In many West African countries like Nigeria, kolanut is a cultural staple prized for its good effects on the body system [22]. It can be described as a unifying plant since the Yorubas cultivate the plant, the Hausas distribute and market it, while the Igbos celebrate and respect this fruit [23].

Although fresh kolanuts are widely available for sale in West Africa, in the United States of America (USA) you're more likely to encounter it in the form of an extract [19]. Today, kolanut is mostly cultivated in Africa, with a large proportion of it coming from Nigeria. Brazil, the West Indies, the Ivory Coast, Sierra Leone and Ghana are also known producers. These six countries alone produce over 250,000 tons annually, while about 300,000 tons are produced worldwide each year [10]. A significant proportion of Nigerian population who are involved in kola farming, trading and industrial utilization; see kolanut as an important economic cash crop. However, Nigeria accounts for about $70 \%$ of the total world production [24].

The standard of living of those involved in kola trading activities in both rural and urban centers are raised due to its economic contribution to both domestic and national markets. Kolanut is an important article of trade in Nigeria, exported in substantial quantities to other African countries, Europe and America. The internal kolanut market in Nigeria is estimated to worth about, thirty million naira ( $\$ 30,000,000)$. The white and bright coloured nuts are said to attract more money than the red and dull coloured nuts [23]. The objective of this study was to identify the uses of kolanut, benefits and negative effects of kolanut consumption. 


\section{Methodology}

This article adopted desk literature using findings from various past published literatures, and Food and Agricultural Organization (FAO) statistics on kolanut. The benefits, side effects and uses were thus identified.

\section{Utilisation of kolanut}

Kolanut is one of the most common masticatory in Nigeria [25]. It has a social and a traditional significance as it features in many traditional ceremonies in Nigeria. It also has industrial use in soft drinks production, pharmaceuticals, and wines and in confectionaries [24]. The edible fruit of the kola tree is also used in beverages as a flavouring ingredient and is the original of the term cola [26]. It is quite bitter, but when the whole-fruit is chewed, it gives a feel of sweet fruity taste. Moreover, it has a pleasant aroma that gives you the smell of rose petals [27].

According to Osborn [7], when the nuts are dried, the taste becomes milder and they reportedly smell of nutmeg. The kolanut is used as supplement for energy increase or health improvement and to flavour sodas [18]. It was reported that in the 1800s in Georgia, John Pemberton who was a pharmacist mixed the extracts of cola with coca, sugar, carbonated water and other ingredients, which resulted in the invention of the first cola drink that he named coca-cola. Cocaine was prohibited in the USA for making soft drinks after 1904 and since then, coca and kola have not been used by coca-cola in the original recipe but manufactured synthetic chemicals that provides a similar flavour of kolanut [15].

The dark brown bubbly beverage beckoning from billboards actually has origins in a West African nut from the kola tree (Cola acuminata and Cola nitida). The term "Cola" is most familiar as a carbonated soda flavour in the Western world. Both coca-cola and Pepsi-cola were born as health tonics in the $19^{\text {th }}$ century with kolanut in the original recipe. The kolanut is still widely consumed for its caffeine content while coca-cola and Pepsi now use synthetic flavours in their sodas. It is still used as an ingredient in some smaller soda brands, though less common today [19]. The nut is often chewed raw, and may also be used in powder form after drying and grinding. The caffeine and other constituents can be extracted through boiling [23]. The kolanut is rich in caffeine, also found in coffee, tea, and mate and in small amounts in chocolate. The nuts have higher caffeine content than coffee and are why they're often chewed in their native Africa as a stimulant [9].

\section{Benefits of kolanut consumption}

Kolanuts have been researched to have many health benefits, however, they still have some effects which when consumed in large quantities are dangerous [27]. Stories about the many health benefits of kolanut go back thousands of years [7]. Kolanut is likely safe for most people when consumed in amounts found in foods [5]. The kolanut contains 2 to 3 percent caffeine and 1 to 2 percent theobromine, both of which act as stimulants when consumed [18]. According to Ayeni [22], kolanut contain substances that stimulate the body, as such may be a helpful natural remedy for some common conditions; but may not be appropriate for everyone. Kolanut has been associated to a number of strong benefits because of its rich caffeine, theobromine and disease-fighting antioxidants content [12]. The kolanut and its extract have been used in health supplements, performance enhancers and energy drinks in recent times [23]. In Europe and the United States, kolanut powder is more readily available than the nuts themselves. A serving of $0.69 \mathrm{mg}$ of kolanut extract equates to a single serving of caffeine [9]. According to Sefianu [23], there have been claims that kolanut sweetens stale water, helps to treat fatigue as well as easing hunger pains.

Osborn [7] reported that most of these claims should be seen as folklore because they are yet to be scientifically researched and proven. Similar to the findings of Sefianu [23]; Techealth Liberia [28]; Decker [9] and AgroNigeria [29], De Pietro [18] found that kolanut produces maximum metabolic rate in the body. Also, Link [12] reported that the caffeine content in kolanut enhances energy levels by altering the activity of certain neurotransmitters in the brain, leading to increased energy level, focus and alertness. In addition, she reported that consumption of moderate amount of caffeine could enhance endurance, brain function and mood while reducing the sensation of fatigue. The seed of kolanuts possess antioxidant properties and enzyme prevention, which are the possible mechanisms for which kolanuts are used for managing type2 diabetes in folklore [15].

According to Obed [30], kolanut is also partly a performance enhancer as a result of its stimulating effect, as such; labourers use it as a source of energy to keep working. In their study, Lowe et al [31] suggested that the kolanut shows promising results against microbes, because its fruits showed anti-microbial activity against Bacillus subtilis, Staphylococcus aureus, Escherichia coli, Klebsiella pneumonae, Pseudomonas aeruginosa and Candida albicans when compared with antibiotics and antifungals Gentamicin and Nystatin. Kolanut is also known to be an appetite 
suppressant because of its caffeine content. This may perhaps be due to the positive impact on metabolism that the nuts can have, kolanut extracts have also been connected with increased fat burning [32].

Kolanut is a performance enhancer, a weight loss supplement, treats headache, cough, tuberculosis, diarrhoea, and bacterial infection and improves cardiovascular health. It also acts as a stimulant in energy drinks. So effective is kolanut that its fruit, bark, seeds and nuts are used to wade away cough and fever, going by folklore. All these health benefits can be linked up to a flavonoid present in it, which has influenced its use for medical purpose in African continent [33]. The caffeine, theobromine, and kolanin content in kolanut can stimulate the heart rate, thus increasing blood circulation. Oxygenation can be boosted to certain parts of the body like the organs, skin and brain through this action. Increased oxygen levels in the brain have been linked with increased concentrating and higher cognition [34]. Kolanut provides stronger resistance by keeping the system away from harmful toxins. Its antioxidant properties wipe out free radicals from the body and produce an effective immune response against foreign materials. It also reported that kolanut retards prostate cancer because kolanut have aiding compounds that are considered as anti-inflammatory drug, which often produces a continuous reaction that can retard the development of the prostrate cell [29].

\section{Negative externalities of kolanut consumption}

It is likely unsafe to take kolanut by mouth in very large amounts due to its caffeine content. Very high amounts of caffeine can cause death. According to Rxlist [5], about 10-14grams is the estimated fatal quantity; that is 150-200mg of caffeine per kilogram of body weight. The side effect of kolanut and kolanut extracts are comparable to those of caffeine. Caffeine affects people differently and about $400 \mathrm{mg}$ of caffeine per day can be safely tolerated by most people [23]. However, depending on how much of the nut is consumed, the side effect of kolanut may vary [35]. It was reported that too much caffeine is particularly hazardous when combined with alcohol and can cause health problems. Alcohol and caffeine combination can lead to alcohol poisoning and drunk driving. Similarly, excessive consumption of caffeine leads to hallucination, which causes one to think he is less impaired than he actually is [7]. Kolanuts and products containing kolanut may not suit everyone. Kolanut should be avoided by anyone who is allergic to the nuts. Allergic reactions to kolanut may include hives, breathing difficulties and stomach upset [18].

Furthermore, blood clotting might be slowed as a result of the caffeine content in kolanut. This is the reason for some medical experts' concern that kolanut might worsen bleeding disorders [5]. Daytime is the best period of the day to consume kolanut because there are higher chances of physical activity, which helps, in the complete utilization of the caffeine. Night consumption of kolanut can cause insomnia, which in turn can impact other functions of the body [28]. According to Adekanye [27], kolanut can put a negative impact on the Central Nervous System (CNS) and the Peripheral Nervous System (PNS) because it is an active stimulant and its powerful effect can cause anxiety and tremors, which are difficult to handle. Kolanuts are high in caffeine, as such, it is very important to consume it in moderation. Caffeine is not only addictive but consuming large quantities can cause fidgeting, nervousness, hyperactivity and sleep disorders [12]. Also, people suffering from osteoporosis or low bone density are advised to limit their caffeine intake to less than $300 \mathrm{mg}$ per day (approximately 2-3 cups of coffee) or consume extra calcium to make up for the amount that may be lost in urine because caffeine in kolanut might increase the amount of calcium that is flushed out in the urine. Also, because vitamin D works with calcium to build bones, older women with inherited disorders that affect the way vitamin $\mathrm{D}$ is used should cautiously consume kolanut [5].

Obed [30] reported that patients with duodenal or peptic ulcer disease should avoid kolanut because of the acidic effect on the stomach, which could worsen the symptoms of ulcer. Over eating kolanut may lead to stomach upset and may also cause stomach pains as a result of increase in stomach acid production caused by kolanut [35]. According to Fashionlady [33], in a study carried out at the University of Bristol, the results showed that due to nervousness and restlessness even $70 \mathrm{mg}$ of caffeine consumption led to unsteady hands. As a result of limited research on the safety or potential side effects of kolanut, caffeine is not recommended for infants, children and adolescents [12].

Also, pressure inside the eye may be increased as a result of the caffeine in kolanut. The increase might occur within 30 minutes and persevere for at least 90 minutes. Caffeine in kolanuts especially when taken in large quantities can worsen diarrhea [5]. Kolanut contains stimulant properties that increase the blood pressure. Old people are more susceptible as such should seek the advice of a medical doctor before consumption of kolanut [22]. Moreover, the American Herbal Products Association includes kolanut on a list of caffeine-containing substances that should not be used by pregnant or breastfeeding women or those under the age of 18 [7]. It was reported that intake of larger quantities of kolanut during pregnancy may increase the chance of miscarriage, early delivery and low birth weight. Hence, nursing mothers should observe closely the consumption of kolanut and ensure it is in low amounts because caffeine passes into breast milk. In addition, irritability, sleep disturbances and increased bowel movement in breast-fed infants are some of the effects of caffeine from kolanut consumption [5] 


\section{Conclusion and recommendation}

The study revealed that kolanut could be chewed fresh. Its extracts have been used as food additives and in flavouring energy drinks. Kolanut is a helpful natural remedy for some common health conditions. However, because kolanut contain some chemical substances like caffeine, theobromine, tannins, phenolics and kolanin that act as stimulants on the body, kolanut may not be appropriate for everybody. Kolanut has its many benefits and side effects and as such is recommended that it should be taken in moderate amounts. Excessive consumption of caffeine can be dangerous and lead to unpleasant side effects. Most people can tolerate about 400 milligrams of caffeine per day, though caffeine can affect people differently.

The appropriate quantity of kolanut consumed depends on several factors such as the user's age, health, physiological status and several other conditions. More research should be carried out on the safety and potential side effects of kolanut. Similarly, specific and appropriate quantity of kolanut should be consumed in order to bring out the many benefits and also for consumers to be able to avoid the many side effects that may arise from the intake of excessive caffeine from kolanut.

\section{Compliance with ethical standards}

\section{Acknowledgments}

Special thanks to the co-authors who gave their support and worked so hard in the preparation of this study. This list includes Qudus Adebayo Ogunwolu, Chinweike Abednego Ugwu, Modinat Adewunmi Alli, Kehinde Ademola Adesanya, Mutiat Oluwaseyi Agboola-Adedoja, Ayodele oladipo Akinpelu.

I am particularly grateful to Dr. Ayodele Oladipo Akinpelu. He was so open in his role as an object of critical evaluation and in proofreading the manuscript. Without his vast experience, this publication wouldn't be possible today. Thank you.

Thanks to Mbre Samuel Assam and my entire family for their encouragement while working on this study. In addition, I would like to thank the editor of World Journal of Advanced Research and Reviews (WJARR) for accepting to publish this work after thorough examination.

\section{Disclosure of conflict of interest}

The authors have no conflict of interest to declare. All co-authors have seen and agree with the contents of the manuscript and there is no financial interest to report. We certify that the submission is original work and is not under review at any other publication.

\section{References}

[1] Mission 2015. Biodiversity for sustainable development: $21^{\text {st }}$ Conference of the parties to the United Nations Framework Convention on Climate Change (UNFCCC COP-21). Paris; 2015.

[2] Robert T. The Importance of tree crops in sustainable agriculture [Internet]. The Channon, NSW: Permaculture Research Institute; (C) 2017 [cited 2020 Nov 23]. Available from https://www.permaculturenews.org/2017/11/27/importance-tree-crops-sustainable-agriculture/.

[3] Chiras DD, Reganold, JP. Natural resource conservation: management for a sustainable future. $9^{\text {th }}$ ed. Prentice Hall: Upper Saddle River, NJ; 2004.

[4] Mclvor I, Youjun H, Daoping L, Pu Z. Agroforestry: conservation trees and erosion prevention. Encyclopedia of agriculture and food systems; 2014. p. 208-21.

[5] RxList. Colanut [Internet]. Califonia: WebMd; (C) 2019 [cited 2020 Nov 23]. Available from https://www.rxlist.com/cola_nut/supplements Internet.htm

[6] Adefule K. Kolanut: a common factor [Internet]. Texas: The234project; (C) 2015 [cited 2020 Dec 4]. Available from https://the234project.com/arts-and-culture/Nigeria/kola-nut-a-common-factor

[7] Osborn CO. What is Kolanut? [Internet]. Califonia: Healthline Media; (C) 2018 [cited 2020 Nov 19]. Available from https://www.healthline.com/health/kolanut 
[8] Oestreich-Janzen S. Caffeine: characterization and properties. Encyclopedia of Food and Health. Amsterdam: Elsevier Ltd; 2016. p. 556-72.

[9] Decker F. What does the real kolanut do to the body? [Internet]. New York: Hearst Communication, Inc; (C) 2018 [cited 2020 Nov 19]. Available from https//www.healthyeating.sfgate.com

[10] Herbazest. kolanut. [Internet]. Orlando: Herbazest Inc; (C) 2020 [cited 2020 Nov 2]. Available from https//www.herbazest.com/herbs/cola-nut/.

[11] Kanoma AI, Muhammad I, Abdullahi S, Shehu K, Maishanu HM, Isah AD. Qualitative and quantitative phytochemical screening of colanuts (Cola nitida and Cola acuminata). Journal of biology, agriculture and health care. 2014; 4(5):89-97.

[12] Link R. Kolanut: The little-known ingredient that supports energy levels [Internet]. Nashville: Dr. Axe; C 2020 [Cited 2020 Nov 2]. Available from https://drake.com/nutrition/kolanut/.

[13] FAOSTAT. Countries by commodity [Internet]. Rome: FAO; (C) 2018 [cited 2020 Nov 5]. Available from https://www.fao.org/faostat/en/\#rankings/countries_by_commodity

[14] Nnenne 0. Kolanut: the food of the ancestors. [Internet]. Los Angeles: Afro style magazine; C) 2013 [cited 2020 Nov 24]. Available from htpps://www.afrostylemag/ASM9/the-kola-nut.htm/.

[15] Healthbenefitstimes.com. Health benefits of kolanut. [Internet]. Healthbenefitstimes; (C) 2020 [Cited 2020 Nov 30]. Available from https://www.healthbenefitstimes.com/ health-benefits-of-kola-nut/.

[16] Your Health Remedy. Kolanut: side effects, benefits, caffeine content, allergy symptoms [Internet]. Your Health Remedy; (C) 2018 [Cited 2020 Nov 24]. Available from https://www.yourhealthremedy.com/harmfulcompounds/kola-nut-side-effects-warnings/.

[17] Mayaki VO. Nigeria: kolanut- A true Symbol of our culture[Internet]. Abuja: Leadership weekend; (C) 2013 [Cited 2020 Nov 24]. Available from https://allafrica.com/stories/20110591228.htm/.

[18] De pietro M. Health benefits of kolanut [Internet]. East Sussex: Medical News Today; (C) 2017 [Cited 2020 Nov 6]. Available from https://www.medicalnewstoday.com

[19] Beyer AL. Curious about the Kolanut? [Internet]. New York: Greatist; (C) 2020 [Cited 2020 Nov 6]. Available from https://www.greatist.com/health/kolanut\#forms-and- uses

[20] Chidume CG, Osisioma US, Echem SO. The Symbolism of Kolanut in Igbo Cosmology: a re-examination. International Journal of Research in Humanities and Social Studies. 2015; 2(8):51-6.

[21] Kanu IA. The Igbo-African Kolanut as a symbolic manifestation of 'Igwebuike' philosophy. Nnadiebube Journal of Education in Africa. 2020; 6(1):2020.

[22] Ayeni O. These side effects of kolanuts will make you reconsider its consumption [Internet]. Lagos: Pulse Nigeria (C) 2019 [Cited 2020 Dec 1]. Available from https://www.pulse.ng/lifestyle/beauty-health/kola-nutside-effects

[23] Sefianu A. Kolanut: benefits and Cautions [Internet]. Lagos: Pharmanews; (C) 2020 [Cited 2020 Nov 27]. Available from https://www.pharmanewsonline.com/kola-nut-benefits-and-cautions

[24] Asogwa EU, Otuonye AH, Oluyole KA, Ndubuaku TCN, Uwagboe EO. Kolanut production, processing and marketing in the south eastern states of Nigeria. American-eurasian J. agric. and environ. sci. Ethiopian journal of environmental studies and management. 2012; 13(2\}:2020.

[25] Umoren E, Osim EE, Udoh PB. The comparative effects of chronic consumption of kolanut (Cola nitida) and caffeine diets on locomotor behaviour and body weight in mice. Nigerian journal of physiological sciences. 2009; 24(1):73-8.

[26] Burdock G, Carabin IG, Crincoli CM. Safety assessment of kolanut extract as a food ingredient Food and chemical toxicology. 2009; 47(8):1725-32.

[27] Adekanye M. 6 unknown health effects of kolanut [Internet]. Lagos: Guardian Newspaper Ltd; (C) 2019 [Cited 2020 Nov 1]. Available from https://guardian.ng/life/some-unknown-health-hazard-of-kola-nut

[28] Techealth Liberia. Benefits of Kolanut and its side effects [Internet]. Monrovia: Techealth Liberia; (C) 2018 [Cited 2020 Nov 16] Available from https://techealth.info/benefits-of-kola-nut-and-its-side-effects/. 
[29] Agro Nigeria. Kolanut: its benefits and side effects [Internet]. Lagos: Agro Nigeria; (c) 2019 [Cited 2020 Nov 1]. Available from https://agronigeria.ng/tag/kolanut/.

[30] Obed D. Excessive intake of kolanut is dangerous, says doctor [Interrnet]. Lagos: Vanguard Media Ltd; (C) 2013[Cited Nov 2]. Available from https://www. vanguardngr.com/2013/01/excessive-intake-of-kola-nut/.

[31] Lowe HIC, Watson CT, Badal S, Peart P, Toyang NJ, Bryant J. Promising efficacy of the Cola acuminata plant: a mini review. Advances in biological chemistry. 2014; 4: 240-45.

[32] Machunga S. Eat me: five surprising health benefits of kolanut [Internet]. Abuja: The Cable Newspaper; (C) 2018 [Cited 2020 Nov 17]. Available from https://lifestyle.thecable.ng/five-health-benefits-of-kolanut/.

[33] Fashionlady. For health enthusiasts: take a look at kolanut side effect [Internet]. Andhra Pradesh: Fashionlady; (C) 2015 [Cited 2020 Nov 24]. Available from htpps://www.fashionlady.In/ for-health-enthusiasts-take-a-lookat-kolanut/.

[34] Purohit MP. 7 health benefits of kolanut [Internet]. Champaign: DoveMed; (C) 2018 [Cited 2020 Nov 25]. Available from https://www.dovemed.com/healthy-living/natural-health/7-health/.

[35] Daily Advent Nigeria. Must Read: here are the side effects of eating kolanut (obi) [Internet]. Lagos: Daily Advent Nigeria; (C) 2018 [Cited 2020 Nov 20]. Available from https://www.dailyadvent.com/health/2018/11/30/ must -read-here-are-the-side-effects/. 